\title{
Ethical Archetypes in Environmental Histories
}

\author{
Mohammed S. Ali \\ Duke University
}

\begin{abstract}
This essay analyzes the ethical archetypes employed by humanists and social scientists to tell stories about human relationships with land. It unfolds from the premise that the ethical concerns authors take to their academic projects enables and constrains the ways they interact with their sources and form the critical judgments they wish to impart to their readers. I survey a cross-section of academic books on the politics of space published within the past decade as well as some classics of environmental history (such as William Cronon's Nature's Metropolis). I set up two major archetypes to understand both the ethical and tropic consequences of these authors' concerns: negative metaphysics and positive metaphysics. These archetypes are opposed to one another and authors in both camps launch mutually hostile broadsides at each other in subtle ways. This essay practices and proposes a method, "historiographical ethics," to make these subtleties obvious so that we may come to grips with what we are doing when we tell stories about our place in the environment.
\end{abstract}

\footnotetext{
Despite the tensions that inevitably exist between nature and our narrative discourse, we cannot help but embrace storytelling if we hope to persuade readers of the importance of our subject. As Aristotle reminded us so long ago, narrative is among our most powerful ways of encountering the world, judging our actions within it, and learning to care about its many meanings. ${ }^{[1]}$
}

\begin{abstract}
Human beings participate in history both as actors and as narrators. The inherent ambivalence of the word 'history' in many modern languages, including English, suggests this dual participation. In vernacular use, history means both the facts of the matter and a narrative about those facts, both 'what happened' and 'that which is said to have happened.' The first meaning places the emphasis on the sociohistorical process, the second on our knowledge of that process or on a story about that process. ${ }^{[2]}$
\end{abstract}

Standard historiographies set out to survey the methodological and theoretical trends of a given field. They may describe these trends and lay out attention-grabbing problems alongside relatively underserved issues. They may consider the possible social and political causes of these trends in relation to ideological developments internal to the field. Regardless of its focus, any given historiography must focus on the knowledge content of scholarship produced in the field of interest. By focusing on knowledge content, standard approaches to historiography risk ignoring the ethical trends and narrative tropes undergirding knowledge production across intellectual communities. This is not to say that standard historiographies are devoid of ethical concerns: claims that scholars are overlooking important primary sources or failing to account for theoretical inconsistencies frequently make appeals to ethical urgency. These appeals may take the form of calling for more inclusive scholarship or reckonings with systematic biases and epistemic violence carried out by unreflexive inquiry. ${ }^{[3]}$ I wish to catalyze a wider variety of mutations between ethics and historiography by building a historiographical ethics: a specialized mode of analysis devoted to the types of moral claims historians (and academics more broadly) make alongside their empirical arguments. 
Since this project is a proof of concept, it does not hinge on proving a thesis in the traditional sense. Instead, it constructs two ethical archetypes based on patterns in different strains of academic scholarship on environmental history. I refer to one of these archetypes as "negative metaphysics" to refer to narratives which advance by opening and then closing diverse strands, such as how William Cronon charts Nature's Metropolis through the rise and fall of the Great West's industrial economy. ${ }^{[4]}$ I call the latter archetype "positive metaphysics" to refer to narratives which advance by opening and then proliferating diverse strands, such as how Anna Tsing structures The Mushroom at the End of the World as a "riot of short chapters... an always too many." [5]

Although I analyze weaknesses in both ethical archetypes, I refrain from arguing that one ethical archetype is superior to the other. Rather, I sketch out a possible set of concepts academics might use in order to develop historiographical ethics of their own. These concepts are provisional: tools rather than rules. Throughout this sketch, I deploy concepts that elaborate on prior concepts and operate at different levels of abstraction: for instance, "closure narratives" is an elaboration on "negative metaphysics." [6] These concepts also generate oppositional pairs, such as "open-ended narratives" for the former and "positive metaphysics" for the latter. Table 1 (below) organizes these concepts, matched horizontally in terms of their abstractness and their oppositional pairings. ${ }^{[7]}$ The vertical ordering roughly coincides with these terms' appearances in this essay.

\section{Table 1: Conceptual Toolkit}

\begin{tabular}{|l|l|}
\hline Positive metaphysics & Negative metaphysics \\
\hline Open-ended narrative & Closed/Closure narrative \\
\hline Expanding social totality & Contracting social totality \\
\hline Unleashed multiplicity & Bounded multiplicity \\
\hline Examination of collective conscience & Meditation on collective death \\
\hline
\end{tabular}

In this paper, I focus on academics working à propos history. They are not necessarily affiliated with specific departments of history. They have published histories of politics and space in the United States. I rely on this loosely defined field in order to zero in on how professional intellectuals seek to articulate ethical obligations between people and the worlds in which they live and depend on for life. Except for Nature's Metropolis-a fielddefining classic - the books I examine here were published within the last decade. I selected them with an eye for award recipients and roundtable review subjects. I take these commemorations as expressions of a collective current in the heterogeneous intertextual oceans that we call fields. Each of these books has generated a paper trail of dialogue following publication. What these books reveal about space is tied to the relationships they articulate between themselves, their readers, space, and text in ways that transcend the basic standards of empirical fidelity the academic guild is designed to ensure. 
The spatial turn across academic disciplines is a turning in two senses: a turning of analytical attention to space, and a turning of space into historical text. This transformation of space into text is key to how scholars make ethical arguments about space. In Power Lines, Andrew Needham makes a clear and representative statement:

Power Lines also reflects the belief that space is a historical text in which can be read the outcome of political struggles as well as a structure that constrains historical agency. This story contains many familiar actors: federal policy makers promoting metropolitan growth, and local businessmen, politicians, and homeowners struggling to turn federal policies toward their own divergent benefits. And it shares the conclusion of the metropolitan synthesis that these struggles have caused profound and enduring geographical inequalities. ${ }^{[8]}$

Textualizing space allows historians to conduct two separate processes. The first concerns the making of space into an object of historical analysis. It presupposes that space is knowable through a proper application of analytical techniques acquired through professional training. The second is to make space into a narrative, to service moral arguments about the consequences of people's actions. These moral arguments take the form of reckonings: faced with the potential for environmental catastrophe, readers must reckon with the hidden costs to human and natural life swept under the rug by a history of exclusionary policies that claimed to serve the general good. These moral arguments also enjoin readers to make sustainable choices about the use of land in the present and, implicitly for the rest of their lives.

When Needham writes about the "many familiar actors" of his "story," he refers to what I think of as spatial fullness. ${ }^{[9]}$ Each historical actor is tied to both a different position within Southwestern space and a different vision of what Southwestern space was and could someday become. The fullness emerges from the multiplicity of actors living on and conceiving of different spaces all contained by what Needham calls "the Southwest." [10] As a history of struggle, each actor, collectively pursuing their political interests and visions for the use of land, is forced to contest, compromise, or ally themselves with other interest groups. In doing so, they must calibrate their respective spatial imaginaries to find a way to coexist and survive the consequences of theirs' and others' changes to the land. They all must live in space in order to imagine it, and they all must imagine space in order to live in it: hence real, or objective space (I will use ur-space: the space that contains all spaces) makes possible and contains every multiplication of spatial imaginaries and consequential actions on that space. This braid between the multiplicity of spatial imaginations by historical actors, and the unity of space as it changes in response to the choices of historical actors, is a narrative structure Power Lines shares with other histories of space, such as Samuel Zipp's Manhattan Projects and William Cronon's Nature's Metropolis. ${ }^{[11]}$

Figure 1 visualizes the narrative structure of Needham, Zipp, and Cronon's books in terms of spatial multiplicities. Each line represents a narrative thread composed of a historical actor combined with their particular spatial imagination. These threads are ultimately derived from a collation and analysis of primary source materials documenting the actions, beliefs, and effects of their actors' world making. Each circle, or node, represents locations where the author draws together all the multiplicities under study into a new spatial unity. However, Figure 1 is incomplete: the regular shape of each node suggests that at each point, the multiplicities are drawn together, and ur-space itself remains constant. In other words, the imaginations and actions of the historical actors have not left a mark on ur-space that affects the characteristics and range of possible multiplicities created by the same historical actors. This is where the workings of power and the moral narrative enter the frame of historical analysis. Figure Two reflects the process by which historical analysis narrates the ways in which space and the consequences of people's actions in and on space constrain historical agency. Figure Two shows how multiplicities of space are constrained by power and changes to the land. Ultimately, these lines meet at a single 
point where total collapse of the land or an insurmountable crisis is either imminent or a grave threat. At this point, the historical narrative reaches closure and raises the call to moral action. Will readers fight to keep multiplicity alive? If not, then they will let the destruction of ur-space come, and therefore put to an end all of the possible ways in which people can live in and imagine it.

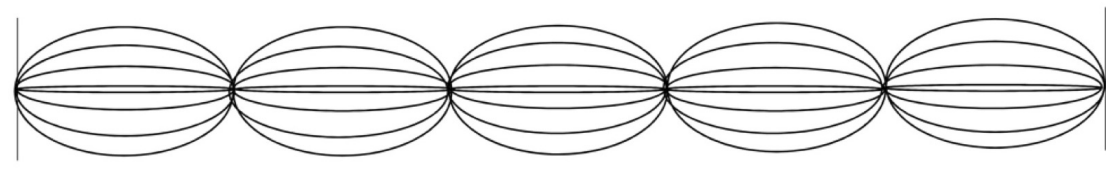

Figure 1: Narrative structure via spatial multiplicities

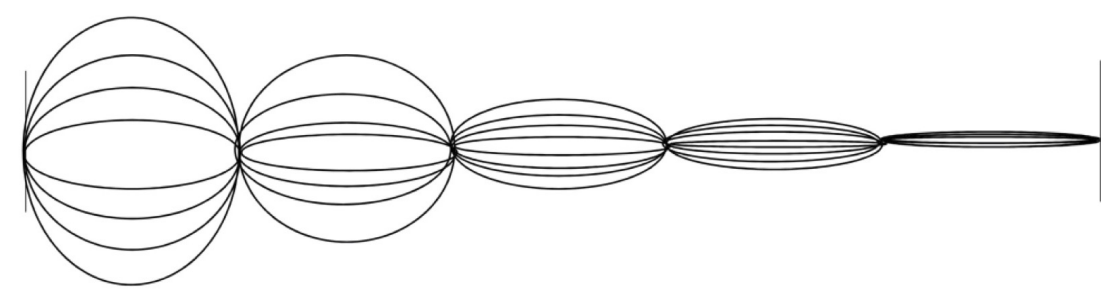

Figure 2: Narrative closure via negative metaphysics
As in histories of space, critiques of power often take the form of critiques of the ways in which power unequally constrains the actions, survivability, and overall multiplicities of human existence to the point where every historical actor is threatened. This point of totalizing threat is a basic way to characterize states of crisis. ${ }^{[12]}$ Every narrative thread is ultimately bundled up around the threat of ultimate negation of spatial fullness through the destruction of life and land.

This singular threat of destruction presupposes a different metaphysical foundation to the one I have described thus far. Whereas the former is constructed around spatial fullness via eternal multiplicities (and could be called a positive metaphysics), the latter

is constructed around spatial barrenness via a final closure (and could be called a negative metaphysics). Within each book, a historical analysis of space, which corresponds to a positive metaphysics (Figure 1), is juxtaposed with a moral argument about space, which corresponds to a negative metaphysics (Figure 2). This juxtaposition implies the use of two distinct notions of space hidden under the surface of that single word. In positive metaphysics, space in analyzed as an object of knowledge inclusive of the ways in which people live through and imagine space. In negative metaphysics, space is a subject of history that is threatened by humans' dangerous and unsustainable enactments of power between each other and on the land.

So long as the relationship between these two metaphysical frameworks is brushed under the surface of "space," it will result in three consequences, listed in ascending order of importance.

1. Fixing arbitrary origins. Cutting out, for instance, the cosmic deep history, how the planet Earth came to be formed and invested with life-supporting elements; in other words, the multiplicities undergirding the creation of ur-space alongside the multiplicities of natural forces and changes within ur-space. Instead, by starting with ur-space, multiplicity is made to appear as solely a production of human activities; it suggests that multiplicity begins with human life rather than preceding it, and thus underestimates the place of multiplicity in "natural" life and phenomena. Addressing this point heeds Ted Steinberg's challenge to use "less anthropocentric and less arrogant" notions of human agency-and thus environmental histories -in which human intentions do not necessarily have to command the spotlight. ${ }^{[13]}$ 
2. Narrative closure means the end of multiplicity. This point is related to the preceding one. There is no sense that multiplicity can persist "in nature" after the departure of human beings. It conflates the destruction of space as we know it with the annihilation of ur-space altogether. In other words, the human-centered multiplicity becomes the absolute limit of total multiplicity. Although history is by definition oriented towards the past, this does not foreclose on historians' abilities to make informed, analytically driven speculations about future multiplicities. Anna Tsing's The Mushroom at the End of the World could model how to sidestep narrating environmental crisis as narrative closure. Such an alternative will help historians avoid conflating the impossibility of knowing the future with assumptions about the absence of a future.

3. Ethical paralysis: Closure narratives frequently tend towards conflating being ethical with preserving multiplicity. Yet all actions enable and constrains ranges of multiplicity. At its extreme, overemphasizing the threat of closure can make readers unable to confront the presence of closures in every possible action. There is a danger of kindling a fear of closure of any kind, when in fact closure and multiplicity emerge inseparably through the consequences and costs of any choice made. Since there is no perfect action that does not simultaneously entail closures, the desire to avoid closure of any sort sets an impossible ethical standard for taking action.

Scholars are by no means limited to using negative metaphysics to develop ethical arguments. Some look explicitly to positive metaphysics as a means to resolve the problems with negative metaphysics surveyed above. Anna Tsing suggests that lamenting the death of space is a luxury anthropologists and environmental scientists can ill-afford to use given the generalized precariousness and destruction caused by neoliberal capital accumulation strategies. "In a global state of precarity, we don't have choices other than looking for life in this ruin." ${ }^{[14]}$ Going beyond Cronon's notions of "first" and "second nature" in Nature's Metropolis, Tsing posits her own "third nature" as that which...

...manages to live despite capitalism. To even notice third nature, we must evade assumptions that the future is that singular direction ahead. Like virtual particles in a quantum field, multiple futures pop in and out of possibility; third nature emerges within such temporal polyphony. Yet progress stories have blinded us. ${ }^{[15]}$

Crucially, Tsing takes progress narratives not to mean narratives with triumphant outcomes, but those that have a fixed ending in mind. Progress can move towards either victory or defeat. In both cases, there is a sense of overwhelming narrative progression regardless of its tragic or heroic outcome. Whether the future bodes well or ill for humanity, Tsing's problem with future-oriented narratives is their emphasis on a "single direction ahead." It is in this sense that I understand negative metaphysics to describe any narrative based on closure, whether that is the closure of a triumphant or an infamous history. Negation comes out of closure because it is a negation of all possible multiplicities in order to emphasize a single and seemingly inevitable narrative outcome. Tsing rebukes this single-minded direction in ascensionist and declensionist narratives of Oregon history in a way that could easily function as a critique of Cronon's "A Place for Stories." [16] Tsing writes,

Consider again the snippets of Oregon history with which I began this chapter. The first, about railroads, tells of progress. It led to the future: railroads reshaped our destiny. The second is already an interruption, a history in which the destruction of forests matters. What it shares with the first, however, is the assumption that the trope of progress is sufficient to know the world, both in success and failure. The story of decline offers no leftovers, no excess, nothing that escapes progress. Progress still controls us even in tales of ruination. ${ }^{[17]}$

Whereas Cronon presents ascensionist 'tales of destiny' with declensionist 'tales of ruination' in "A Place for Stories" as the only two options for historical narration, Tsing emphasizes the possibility of narration without progress through her attention to the persistence and possibilities of life within and despite environmental 
destruction. She emphasizes "collaborative survival" in places and times of precarity, "[n]ot that this will save us but it might open our imaginations" to new ways of living with and through our ecosystems. ${ }^{[18]}$

Imagination is a crucial part of both Tsing's and other scholars' narratives who eschew closure and instead utilize what I think of as positive metaphysics. Unlike negative metaphysics, which produces narratives based on closure, positive metaphysics unleashes possibility: it culminates not in closed endings, but open-ended "antiendings." [19] Gaye Theresa Johnson captures positive metaphysics with her concept of "spatial entitlement" in Spaces of Conflict, Sounds of Solidarity: "a way in which marginalized communities have created new collectivities based not just upon eviction and exclusion from physical places, but also on new and imaginative uses of technology, creativity, and spaces." "20] Similar to Tsing's attention to collaborative survival in capitalist ruins, Johnson uses spatial entitlement to illuminate the tactics of survival and solidarity Black and Brown activists and youth forged between themselves to live and exercise their "freedom dreams" in the urban ruins created by the Los Angeles white power structure. ${ }^{[21]}$

Likewise, in Covert Capital, Andrew Friedman emphasizes the importance of imagination in seeing through the seeming blandness and banality of north Virginia suburbs. ${ }^{[22]}$ In his project, this anodyne neighborhood façade gives way to densely interlocking multiplicities entangling this suburb with US imperial projects across the globe. These entanglements arise out of a polyphony of collaborative survivals: CIA officers depended on collaborators in the regimes they sought to support. In retirement, officers nostalgic for their past lives on duty recreated the sights, sounds, and flavors of their globetrotting days by bringing international cuisines and architectural designs to Virginia. When operations failed, as in Tehran or Saigon, Iranian and Vietnamese collaborators relied on their CIA comrades to escape to the United States and establish themselves in and around the north Virginia suburbs where their contacts lived. As with Tsing and Johnson, Friedman's argument is built on finding multiplicity in seemingly barren (or homogeneous) landscapes. Figure 3 offers a narrative structure based on positive metaphysics, taking up Tsing's The Mushroom at the End of the World, Johnson's Space of Conflict, and Andrew Friedman's Covert Capital as examples. Though Figure 3 is identical to Figure 1, I use broken lines after the final node to express the open-endedness of Tsing, Johnson, and Friedman's narratives.

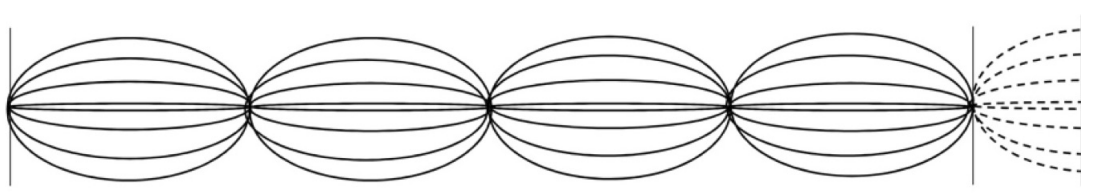

Figure 3: Narrative openness via positive metaphysics
Although narratives based on positive metaphysics may resolve some of the problems I identified with negative metaphysics above, they are not free from ethical problems of their own. Positive metaphysics' emphasis on indomitable multiplicity makes censure difficult and may bleed out the possibility for articulating the moral

urgency of a particular cause. Whether a given crisis is solved or left to fester, life will persist in new and unexpected forms: indomitable multiplicity will persevere no matter what humans do or do not do. If death contains the seeds of life and life contains the seeds of death, then what need is there for justice?

My narrative thus far has presented positive metaphysics as not only an alternative to negative metaphysics, but also specifically a critical response to negative metaphysics. Anna Tsing criticizes William Cronon on just these grounds: his narration presupposes the destruction of life without looking and seeing how life persists in ruined 
landscapes. What do negative metaphysicians have to say about these challenges? Though Cronon has not publically responded to Tsing, it is possible to construct the terms of the debate through a narrative analysis of an environmental historian who has engaged with but ultimately discarded positive metaphysics. In our story, Nancy Langston's Toxic Bodies will play that role. ${ }^{[23]}$

Toxic Bodies sits at the crossroads of environmental history and regulatory history. This elegy narrates the failure of United States regulatory agencies to remove endocrine disruptor chemicals from human consumption and exposure in spite of unambiguous scientific data about harms to human development. The causes of this failure are manifold. Langston traces pro-business coziness between regulatory officials and chemical industrialists, changes in toxicological paradigms that scientists have embraced but not government officials, problems in the reigning US regulatory paradigm of "negligible risk," [24] and the movement of endocrine disruptors from direct application to human bodies to stealthier additives in the production stream of food for human consumption.

Langston rejects positive metaphysics in Chapter 8 of Toxic Bodies, titled "Sexual Development and a New Ecology of Health." Early on in the chapter, Langston notes that successful awareness campaigns on the dangers of diethylstilbestrol (DES) for humans framed the chemical as a threat to normal masculine development in animals. These sensationalist appeals to cultural notions of gender essentialism served as a lightning rod for attracting funds and support for scrutinizing the safety of DES. ${ }^{25]}$

Reacting to such headlines, some cultural theorists dismissed concern with endocrine disruptors as reflecting little more than essentialist assumptions about sexual difference and development. But we cannot easily dismiss endocrine disruptors as a manifestation of cultural anxiety and therefore not of concern to material bodies. Reproductive cancers linked to pollutants are not mere anxieties; they have material reality. Intersexual and transsexual conditions correlated with chemical exposures are not simply what the theorist Judith Butler calls performances playing with cultural norms of gender. ${ }^{\text {[26] }}$

For Langston, materiality stands both as an important corrective to the excesses of cultural theorists' critiques of gender. Materiality is also a condition that both admits and establishes limits to the range of multiplicities available to cultural actors. Yet this is not to say that Langston thinks anti-essentialist cultural critics are too expansive. In fact, she turns the tables on them by making cultural theory seem limited and homogenizing as opposed the dynamism of her New Ecology of the body.

...sex is not a simple matter for humans...Exogenous factors - things outside the body - constantly find their way into endogenous pathways, shaping differences between male and female at the genetic, phenotypic, and cultural levels. Social interactions, for example, can change hormone levels, which can in turn affect bone deposition and mass. [27]

Whether charitable to Butler or not, Langston conducts a rhetorical reversal to claim the high ground of acknowledging the fullest complexity of the human sex-gender system. While Butler's anti-essentialism only admits cultural relativism, Langston is able to parse out "genetic, phenotypic, and cultural levels." In the abstractions of my own analysis, Langston is suggesting that negative metaphysics can admit a greater appreciation for multiplicity than positive metaphysics, even if the latter is invested in the indomitability of multiplicity itself.

How can negative metaphysics outpace positive metaphysics in taking account of multiplicity? Langston reterritorializes the boundedness of negative metaphysics so that it is not about the range of manifestations of gender and sexual possibilities in living organisms, but is about the networks and processes that give rise to living 
organisms in the first place. "Chemical pollutants change the network of genetic, immunological, neurological, hormonal, and environmental interrelationships that control sex and reproduction in vertebrates, and this can kill an individual, eliminate a population, or drive a species extinct."[28] For Langston, this network of interrelated processes, all operating at different levels of scale and that call into necessity different human abstractions, is the motor of multiplicity. For her, DES does not threaten gender per se but the networks - the motors - themselves. The interrelated networks constitute the territory of ur-space, without which multiplicity in any form would be impossible. In this way, Langston subordinates positive metaphysics to negative metaphysics. For her, negative metaphysics furnishes the conditions of possibility for positive metaphysics, but not the other way around.

Toxic Bodies relies on a closed narrative throughout. Langston finishes her book with a pointed discussion of failed pregnancy as one of the lasting legacies of unchecked diethylstilbestrol exposure, before zooming out into a planetary view. In the zoomed-out perspective, Langston admits that there are powerful forces arrayed against removing DES and other industrial chemicals from "our bodies or ecosystems." [29] What if DES is left unchecked? Langston draws ominous parallels to the collapse of financial markets followed by irrationally, ideologically motivated deregulatory policies. For her, "The most important lesson of the DES tragedy is the need for intelligent regulation to protect public health and the environment." ${ }^{[30]}$ Without such policy, our environment might collapse much as our financial markets did-and the possibilities for all life will be bleak.

In Toxic Bodies, Langston argues for a vision of political change in which the state is tethered to social totality. To capture the state-which I am glossing as the institutional organs of government-is key to directing the implementation of one's favored policies in the service of social and environmental protection. In this, Langston's state operates in an analogous way to Cronon's, Needham's, and Zipp's uses of ur-space as the foundation for social totality. This is because ur-space, as the space that contains all spaces, ultimately unifies all of the historical actors of their narratives. The crisis of ur-space/politics both threatens and produces social totality; it endangers every historical actor whether or not they realize it. This connection between the state and ur-space suggests that closure narratives depend on social totality (and the threat of the destruction of social totality) in order to make ethically urgent claims. This social totality articulates a bounded multiplicity that it aims to preserve. For Langston, this takes the form of a certain kind of medico-historical discourse invested in making claims on state regulatory agencies; for Needham and Cronon, this takes the form of a range of sustainable practices for living on and with the environment. Yet because this multiplicity is bounded, closure narratives are also invested in a project of discounting multiplicities that go too far. For example, Langston's chapter discounts the intellectual projects of cultural feminism, while in Nature's Metropolis, Cronon censures certain ways of imagining the citycountryside relationship. For closure narratives, certain multiplicities have to be delegitimized in order to protect social totality; I call this a contracting social totality.

The above should not be taken to mean that open-ended narratives reject social totality. Tsing argues that modern supply chains integrate myriad kinds of production schemes and practices of exchange into overarching structures of capital accumulation. ${ }^{[31]}$ She also uses concepts such as the "latent commons" to describe the "entanglements" between and among human and non-human actors that make collaborative survival possible in circumstances of precarity. ${ }^{[32]}$ Johnson argues for an expansive and future-oriented totality in which Black and Brown solidarity and spatial entitlements redefine and create the possibilities for a better world. Friedman likewise expands totality by tearing down the distinctions between US foreign policy and domestic policy, looking for synergistic pathways through which the US and the world interpenetrate one another through the everyday work 
of empire. ${ }^{[33]}$ Rather than delegitimizing certain strands of multiplicity, authors using a positive metaphysics unleash multiplicity in its myriad manifestations. ${ }^{[34]}$ In other words, such authors rely on an expanding social totality in contrast to the contracting social totality of negative metaphysical scholarship.

Up to this point, my ethical historiography has focused on distinguishing positive from negative metaphysics and open-ended from closed narratives. Yet the distinctions should not be overemphasized. Both ethical architectures situate themselves around constructions of social totality, and both rely on multiplicity and spatial fullness to structure their narratives. A genealogical analysis in the vein of Michel Foucault's lectures on the Stoics might find that the two approaches theorized here descend from a unified ethical formation. ${ }^{[35]}$ The remainder of this essay will outline the foundations for such a genealogy without claiming to make historical arguments about the discursive conditions or chronology of any discontinuities that could account for the split between positive and negative metaphysics.

Stoicism allows us to think of the relationship between negative and positive metaphysics not as a contradiction that needs resolution in a homogeneous framework, but as a coherence of heterogeneous plasmids, spliced together under the species name Philosophica stoica while retaining their distinctive identities. In this spirit, Stoicism points to how negative and positive metaphysics can hang together, rather than presupposing a negation that must be overcome between these two archetypes.

In The Hermeneutics of the Subject, Foucault analyzes how Christian philosophers came to separate selfknowledge from the spiritual practice of caring for the self. For the classical Greeks, no distinction obtained. Selfknowledge was simply one of many practices implicated in and valuable for its contribution to cultivating a virtuous and well-governed self. What concerns me here is Foucault's attention to the practices of the "examination of conscience" and the "meditation on death." [36] For Foucault, these practices, championed by the Stoics, constitute a crucial step in his genealogy through which the whole of life came to be seen as a perpetual test for the self. This set the stage for the discontinuity in Christian philosophy through which self-knowledge came to be separated from the care of the self.

My interest in the examination of conscience and the meditation on death stems from certain similarities between these practices of self-care and the types of ethical arguments surveyed in this study. My goal is not to argue that Stoic philosophy is a major influence in present-day scholarship, but that Foucault's analysis provides useful heuristics for conducting ethical historiographies. The examination of conscience and meditation on death were meant to be complementary practices for the Stoics. I will demonstrate that they have been both modified and separated from one another within the ethical arguments surveyed here.

The examination of conscience begins with the Pythagoreans as a process of purifying the soul through selfexamination. It is a ritual of expiating evil within the soul and making possible a peaceful sleep. Under the Stoics, the examination of conscience takes on different meanings and purposes: in particular, a distinction between a "morning examination" and an "evening examination." The former lays out the commitments and tasks one has planned for the day to remind oneself of the general outlook and aims behind these individual obligations. The latter concerns judging oneself and reviewing "all the day's actions."[37] The purpose of the evening examination is to compare the ends one sets for the day in the morning examination with the means one employs to achieve those ends. If the means are out of proportion to the ends-especially to the extent that they compromise the ends one sets for oneself (Foucault provides the example of Seneca arguing too forcefully with a friend, causing 
the friend to reject the argument) - then this is a fault that must be rectified in the constant cultivation of oneself. It is a matter less about enjoining future conduct and more of calibrating ourselves in accordance with the rules of proper action: "a memory exercise, not just with regard to what happened during the day, but with regard to the rules we should always have in our mind" governing proportionate and proper conduct of ourselves. ${ }^{[38]}$

The examination of conscience resonates with ethical arguments based on positive metaphysics. Johnson exhorts readers to remember collectively every available means of fighting white supremacy: spatial entitlement, soundscapes, and Black-Brown organizational solidarity. Her debt to the examination of conscience takes form in her conviction that the past of the "great future" must not be forgotten because it furnishes powerful principles of action for future struggles. ${ }^{[39]}$ Friedman exhorts readers to look through the seemingly banal and ahistorical suburban façade to see how they are implicated in everyday practices and networks essential to maintaining US Empire. Tsing exhorts readers to practice modes of collaborative survival in danger of being lost to capitalist competitiveness and despair over the undoing of progress narratives. Through an examination of collective conscience, each author mines history to examine principles of conduct claimed and constructed through collective memories, picking through their archives in search of means suitable to the ends of making a better future.

The meditation on death concerns a practice complementary to the examination of conscience. It is a moral exercise that "involves living each day as if it were the last."[40] The meditation on death enables two practices of self-examination. The first is a contextualization of the present. Living life as if in one's final moments raises the stakes of committing to virtuous actions by laying bare their true value. One lives in accordance with the urgency of acting and situating oneself for the moment of death. "Through this kind of gaze of death which you focus on your activity, you will be able to evaluate it, and if you happen to think that there is a finer and morally more worthy activity which you could be engaged in when you die, then this is the activity you should choose." ${ }^{[41]}$ The meditation on death inculcates a perpetual urgency towards acting in accordance with one's moral standards. This urgency is premised on the impossibility of futurity by injecting mortality into the present. The second practice of self-examination is a contextualization that takes up "a retrospective view over the whole of life."[42] It is designed to reveal the sum total of the value of one's life and actions by collapsing the present into the past. This form of self-examination likewise negates futurity in order to establish a sense of urgency and gravity towards choosing the worthiest activities possible.

The meditation on death resonates with ethical arguments based on negative metaphysics. By confronting the death of ur-space, Cronon, Zipp, and Needham seek to reveal the true value of historical actors' ways of living on and through space. They also seek to spur their readers into judging their actions in space carefully. Cronon argues that readers must live in awareness of the symbiotic relationship between city and countryside, lest they commit to unsustainable practices that are oblivious to this mutual connection. Zipp exhorts readers to consider the costs of urban renewal and challenges them to build an alternative to the urban renewal paradigm lest the urban crisis becomes intractable. Needham pushes readers to think critically on the hidden politics as well as the human and environmental costs of enjoying electricity on-demand. Their meditations on death do not directly rely on exhorting readers to imagine their own deaths in order to bring into relief the urgency of their ways of being and acting in the world. They orient self-examination towards a collective death implied by the destruction of urspace. They hope to change readers' actions by convincing them to live not as if it is their last day to live per se, but the land's. 
It is not my purpose to analyze how and why the examination of collective conscience and the meditation on collective death came to be seen as antithetical ethical archetypes for modern scholars. Nevertheless, the scholarship surveyed here consistently holds out one option at the expense of another. Authors like Langston cast negative metaphysics as a corrective to the Pollyannic excesses of positive metaphysics' affirmation of politics and resistance to power broadly conceived. Authors like Anna Tsing and Gaye Theresa Johnson cast positive metaphysics as the solution to negative metaphysics' overly narrow and ultimately fragile dependence on narratives of progress and myopic views of political possibility. Yet Foucault's Stoics developed the examination of conscience and the meditation on death as complementary practices. The examination of conscience entailed keeping at hand the correct and proportionate means to achieving one's ends (and, by implication, establishing those ends with precision). The meditation on death calibrated those ends with respect to the finality of death: one should act deliberately and in accordance with one's authentic values, stripped of carelessness and compromise as if mortality were a distant fate. Foucault's genealogy suggests that it is possible to splice positive and negative metaphysics through sustained attention to the construction of ethical archetypes.

Historiographical ethics is my attempt to name and systematize this practice of sustained attention to what environmental histories do for their readers. For positive metaphysicians, environmental history is a means to inspire hope and provoke new possibilities for coexistence. For negative metaphysicians, environmental history is a means to alert readers to catastrophe and impart sobering wisdom. In both archetypes, histories are meant to work on their readers, to change our ways of being in the world.

Like words for the later Wittgenstein, histories are akin to the contents of a toolbox. Histories are instruments for measurement, construction, disassembly, and protection. ${ }^{[43]}$ Their functions are determined by specific ends: to warn; to teach; to inspire; to laugh. If we are to notice what history does, then we must expand the scope of our vision, beyond narrow disciplinary concerns with the truth-value of specific historical narratives. It does not make sense to say that negative metaphysics is right and positive metaphysics is wrong. They are ways of doing things that should be judged on felicity-their effectiveness for transforming readers.

In an essay dedicated to analyzing the ethical techniques employed by scholars, it has been difficult for me to decide how to employ ethics for my own purposes. In justifying the practice of historiographical ethics, should I use positive metaphysics or negative metaphysics? On the one hand, I have suggested that historians' failure to pay attention to historiographical ethics will lead to a totalizing crisis of faith in the power of the profession to change the world. On the other, I have also suggested that historiographical ethics pays attention to and paves the way for new possibilities of knowledge production amidst the post-truth eutrophication wrought by postmodernism. Ideally, I would have been able to braid both archetypes here. Let me cast the first plasmid, so my readers can splice it with their own.

\section{Acknowledgements}

Many thanks to Adriane Lentz-Smith, Jessica Hauger, Brad Wood, and Charlotte Schwarz for their comments on my manuscript drafts. To Wujun Ke and Brad Wood for our many conversations about Deleuze. To Faizan Syed and Evan Nash for hosting me over an extended revisions retreat. To Dianne Chishom and Ellen Berry for their critical commentary and enthusiasm for this project. 
An Charlotte, für die Archetyp und alle unsere Kleeblätter.

\section{References}

Cronon, William. "A Place for Stories: Nature, History, and Narrative." The Journal of American History 78:4 (March 1992), 1347-1376.

—. Nature's Metropolis: Chicago and the Great West. New York: W.W. Norton \& Company, 1991.

Deleuze, Gilles. Bergsonism, trans. Hugh Tomlinson and Barbara Habberjam. New York: Zone Books, 1988.

Foucault, Michel. The Hermeneutics of the Subject: Lectures at the Collège de France 1981-1982, trans. Graham Burchell, ed. Frédéric Gros. New York: Picador, 2005.

Friedman, Andrew. Covert Capital: Landscapes of Denial and the Making of U.S. Empire in the Suburbs of Northern Virginia. Berkeley: University of California Press, 2013.

Johnson, Gaye Theresa. Spaces of Conflict, Sounds of Solidarity: Music, Race, and Spatial Entitlement in Los Angeles. Berkeley: University of California Press, 2013.

Kelley, Robin D.G. "Beyond the 'Real' World, or Why Black Radicals Need to Wake Up and Start Dreaming." Souls 4:2 (2002), 51-64.

Klingle, Matthew, James Allison, Julie Cohn, and Robert Lifset. "Needham, 'Power Lines,'”, ed. Christopher F. Jones. H-Environment Roundtable Review 9:4 (2019). https://networks.h-net.org/needham-power-linesroundtable-review-vol-9-no-4-2019

Kramer, Paul A. "Power and Connection: Imperial Histories of the United States in the World." The American Historical Review 116 (December 2011), 1348-1391.

Needham, Andrew. Power Lines: Phoenix and the Making of the Modern Southwest. Princeton: Princeton University Press, 2014.

Langston, Nancy. Toxic Bodies: Hormone Disruptors and the Legacy of DES. New Haven: Yale University Press, 2011.

Levins, Richard. "Strategies of Abstraction.” Biology \& Philosophy 21 (2006), 741-755.

Lytle, Mark Hamilton and Frederick Rowe Davis, Thomas R. Dunlap, and Stephen Bocking, "Nancy Langston, 'Toxic Bodies: Hormone Disruptors and the Legacy of DES,'” ed. Jacob Darwin Hamblin, H-Environment Roundtable Review 2:2 (2012), https://networks.h-net.org/nancy-langston-toxic-bodies-hormone-disruptors-andlegacy-des-roundtable-review-vol-2-no-2-2012 
Steinberg, Ted. "Down to Earth: Nature, Agency, and Power in History." The American Historical Review 107:3 (June 2002), 798-820.

Trouillot, Michel-Rolph. Silencing the Past: Power and the Production of History. Boston: Beacon Press, 1997.

Tsing, Anna Lowenhaupt. The Mushroom at the End of the World: On the Possibility of Life in Capitalist Ruins. Princeton: Princeton University Press, 2015.

White, Hayden. "Narrativity in the Representation of Reality," in The Content of the Form. Baltimore: Johns Hopkins University Press, 1990.

Wittgenstein, Ludwig. Philosophical Investigations, fourth edition, trans. G. E. M. Anscombe, P. M. S. Hacker, and Joachim Schulte. Oxford: Blackwell Publishing, 2009.

Wolfe, Patrick. "Settler Colonialism and the Elimination of the Native." Journal of Genocide Studies 8 (December 2006), 387-409

Zipp, Samuel. Manhattan Projects: The Rise and Fall of Urban Renewal in Cold War New York. Cambridge: Oxford University Press, 2012.

\section{Notes}

1. Cronon, William. "A Place for Stories: Nature, History, and Narrative." The Journal of American History 78:4 (March 1992), 1375.

2. Trouillot, Michel-Rolph. Silencing the Past: Power and the Production of History (Boston: Beacon Press, 1997), 2.

3. Standard historiographies include Patrick Wolfe "Settler Colonialism and the Elimination of the Native" in Journal of Genocide Studies 8 (December 2006), 387-409; Paul A. Kramer, "Power and Connection: Imperial Histories of the United States in the World" in The American Historical Review 116 (December 2011), 1348-1391; and Ted Steinberg. "Down to Earth: Nature, Agency, and Power in History" in The American Historical Review 107:3 (June 2002), 798-820.

4. Cronon, William. Nature's Metropolis: Chicago and the Great West (New York: W.W. Norton \& Company, 1991). Awards: https://www.williamcronon.net/books.html

5. Tsing, Anna Lowenhaupt. The Mushroom at the End of the World: On the Possibility of Life in Capitalist Ruins. (Princeton: Princeton University Press, 2015), viii. Awards:

https://press.princeton.edu/titles/10581.html

6. Why abstractions, and why so many elaborations? Each concept in Table 1 is meant to operate from different sets of givens to illuminate (and obscure) different aspects of ethical archetypes. I take my lead from Richard Levins who observes, "Different abstractions from the same wholes capture different aspects of the reality but also leave us with different blindnesses." Richard Levins, "Strategies of Abstraction," Biology \& Philosophy (2006) 21:742-3. My thanks to Leon Li for this reference.

7. David Harvey's tables in The Condition of Postmodernity: An Enquiry into the Origins of Cultural Change (Oxford: Blackwell Publishers, 1989) inspired my conceptual toolkit. One could conceive of my archetypical divergence in terms of a modernist-postmodernist binary. I will leave that line of flight to the reader.

8. Needham, Andrew. Power Lines: Phoenix and the Making of the Modern Southwest (Princeton: Princeton University Press, 2014), 19. Awards: https://press.princeton.edu/titles/10369.html. For its H-Net 
Roundtable Review, see Matthew Klingle and James Allison et al, "Needham, 'Power Lines,'” ed. Christopher F. Jones, H-Environment Roundtable Review 9:4 (2019), https://networks.h-net.org/needhampower-lines-roundtable-review-vol-9-no-4-2019

9. My "spatial fullness" is related to Hayden White's "narrative fullness." His fullness concerns historians filling gaps in chronology (contradistinct from the annalist). Narrative fullness comes out of a density of sources and events, which resonates with my understanding of multiplicity as it concerns spatial fullness. White, Hayden. "Narrativity in the Representation of Reality," in The Content of the Form (Baltimore: Johns Hopkins University Press, 1990), 9.

10. My understanding of multiplicity is indebted to Gilles Deleuze's interpretation of Henri Bergson's philosophy of duration.Multiplicity refers to the irreducible heterogeneity of life and its continuously evolving manifestations. I use multiplicity in the context of history to describe historical narration as a process of eliciting different strands of events, archives, and materials as actualizations of heterogeneous social, politics, and environmental-economic forces. As I argue below, though all historical narratives rely on multiplicity, they respond to it in different ways. Deleuze, Gilles. Bergsonism, trans. Hugh Tomlinson and Barbara Habberjam (New York: Zone Books, 1988).

11. Zipp, Samuel. Manhattan Projects: The Rise and Fall of Urban Renewal in Cold War New York (Cambridge: Oxford University Press, 2012). Awards: https://global.oup.com/academic/product/manhattan-projects9780199874057

12. For states of crisis, I have in mind situations such as those Zipp characterizes at the end of Manhattan Projects: "Perhaps the greatest tragedy of urban renewal is that its failure left us with no comprehensive vision for how to deal with the perils of global urbanization and little political will to develop one." 371.

13. Steinberg, "Down to Earth," 819-820.

14. Tsing, Mushroom, 6.

15. Ibid, vii.

16. What I am referring to as ascensionist narratives, Cronon refers to as "progressive" narratives. Cronon, "A Place for Stories," 1352.

17. Tsing, Mushroom, 22.

18. Ibid, 19.

19. This is the title of Tsing's penultimate chapter in Mushroom.

20. Johnson, Gaye Theresa. Spaces of Conflict, Sounds of Solidarity: Music, Race, and Spatial Entitlement in Los Angeles (Berkeley: University of California Press, 2013), ix. Awards: https://www.ucpress.edu/book/9780520275287/spaces-of-conflict-sounds-of-solidarity

21. Johnson, Spaces of Conflict, 239.

22. Friedman, Andrew. Covert Capital: Landscapes of Denial and the Making of U.S. Empire in the Suburbs of Northern Virginia (Berkeley: University of California Press, 2013). Awards: https://www.ucpress.edu/book.php?isbn=9780520274655\#about-book

23. Nancy Langston, Toxic Bodies: Hormone Disruptors and the Legacy of DES (New Haven: Yale University Press, 2011). For its H-Net Roundtable Review, see Mark Hamilton Lytle and Frederick Rowe Davis et al, "Nancy Langston, 'Toxic Bodies: Hormone Disruptors and the Legacy of DES,'" ed. Jacob Darwin Hamblin, H-Environment Roundtable Review 2:2 (2012), https://networks.h-net.org/nancy-langston-toxic-bodieshormone-disruptors-and-legacy-des-roundtable-review-vol-2-no-2-2012

24. Langston, Toxic Bodies, 160.

25. Ibid, 135.

26. Ibid, 136.

27. Ibid, 136.

28. Ibid, 150.

29. Ibid, 164.

30. Ibid, 165.

31. Tsing, Mushroom, 42. 
32. Ibid, 134-135.

33. Friedman, Covert Capital, 5.

34. These open-ended narratives often take the form of both-and arguments. See for instance Robin D.G. Kelley's insistence on the political indispensability of love, poetry, and imagination in addition to the "easy kind of pragmatism" of making claims on the state. Kelley, Robin D.G. "Beyond the 'Real' World, or Why Black Radicals Need to Wake Up and Start Dreaming." Souls 4:2 (2002), 63.

35. Foucault, Michel. The Hermeneutics of the Subject: Lectures at the Collège de France 1981-1982, trans. Graham Burchell, ed. Frédéric Gros (New York: Picador, 2005).

36. Foucault, Hermeneutics, 478 (meditation on death), 480 (examination of conscience).

37. Foucault, Hermeneutics, 481.

38. Ibid, 482, 483.

39. Johnson, Spaces of Conflict, 240.

40. Marcus Aurelius quoted in Foucault, Hermeneutics, 478.

41. Foucault, Hermeneutics, 479.

42. Ibid.

43. Ludwig Wittgenstein, Philosophical Investigations, fourth edition, trans. G. E. M. Anscombe, P. M. S. Hacker, and Joachim Schulte (Oxford: Blackwell Publishing, 2009).

\section{Cite this Essay}

Ali, Mohammed S. "Ethical Archetypes in Environmental Histories." Rhizomes: Cultural Studies in Emerging Knowledge, no. 36, 2020, doi:10.20415/rhiz/036.e01 